\title{
The Impact of Art Education Program on the Social Skills of Preschool Children
}

\author{
Elçin Yazıcı \\ Correspondence: Asst. Prof. Elçin Yazıcı, Duzce University, Faculty of Education, Department of Basic and Preschool \\ Education, Duzce, Turkey.
}

Received: February 17, 2017

Accepted: March 24, 2017 Online Published: March 26, 2017

doi:10.11114/jets.v5i5.2231

URL: https://doi.org/10.11114/jets.v5i5.2231

\begin{abstract}
The current study was carried out to determine the effect of art education program on the social skills of preschool children at the age of 61-72 months attending to a kindergarten. The working group of the research was made up of 51 children in total, as experiment group (n: 26) and control group (n: 25). An experiment design with a pre/post-test control group was used in the study in order to investigate the effect of "Art Education Program" on the social skills of children at the age of 61-72 months. Also, "Social Skills Evaluation Scale/ SSES" was used in the research. In the experiment group, "Art Education Program" was applied about 40 minutes-one hour in three week days for eight weeks in total. As a result of the statistical analysis of the data, it was found that "Art Education Program" applied had an effect in favour of experiment group depending on the mean scores of the children both in experiment and control group with regard to their social skills.
\end{abstract}

Keywords: preschool education, art education, social skills

\section{Introduction}

Art is a creative work expressing the history, culture and spirit of individuals. It is a part of communication and creativity (Jackman, 2012). It is also learning with a high value and of an extensive potential to enrich the educational experiences of children. It is the most effective way of education in setting the unity between perception, thinking and application (Özsoy \& Şahan, 2009). General and educational functions of art in this sense make art education necessary. According to International Standards of Art Education, knowing art and applying the branches of art is the basis of healthy development (Fox \& Schirrmacher, 2014). Meeting with different branches of art presenting various opportunities for the sake healthy development of children in their early ages is necessary in terms of supporting the artistic skills of children in an integrated way (Hardy, 2011).

Of these art branches supporting the integrated developments of children, musical art comprises such activities as singing, playing an instrument, listening to music, making music, musical activities, history of music and its origin. To create their own music, children discover sound and instruments and make rehearses. In this way, it is aimed that they improve their song, rhythm, tongue twister and melody repertoires. In addition, they discover the musical thought through symbols and start to use them in their musical terminology. They start to use and listen to music consciously. They learn how to evaluate and make comments on the musical applications of others. Visual art is defined as the components such as painting, drawing, picture, sculpture, architecture, graphics, photography, and film making and configuration designs. Visual art is a social activity and it also improves the linguistic and thinking skills. Children develop awareness for looking at an artistic study, talking about what they see, using the terminology of visual art language. Kinaesthetic art is defined as the activities depending on body movements. Thanks to kinaesthetic art, children learn how the parts of their bodies move independently and together and in addition, they perceive locomotor and non-locomotor movements. Furthermore, it supports and improves the awareness, physical and cognitive developments. Children discuss and listen to the views of others over their own and others' dances. Dramatic art is defined as discovering, representing and influencing. This type of art increases the self-esteem of the children and supports them in understanding their feelings. Dramatic art is kind of art aiming at providing children with expressing their feelings and having peace. This skill uses the skill of roleplaying, provides them with experiencing their environments through their senses and makes them attain new practical skills for the real life problems. Children discover knowledge and skills through roleplaying (Hardy, 2011; Garvis, 2012; Lucas 2014; Yazıc1, Yaman Baydar \& Pinarckk, 2016). 
All the sub-branches of art education are of importance at the same level and they are much more effective when they are integrated with other branches of disciplines. Children's experience in different branches of arts, their learning of art concepts are of importance in their attaining an artistic and aesthetic perspective. In terms of the features of art branches, these features provide ideas in order to bring cognitive and sensual expressions for the purpose of making children transfer their feelings and thoughts to each other. By making the connections and stimulations, children could attribute a personal meaning on events and can feel authorized in realizing and getting to know themselves (Hardy, 2011). It could help to develop such skills as the sense of self in children, reasoning, imagination, creativity, expressing himself and communication and supports all developmental fields. Because of these supportive components, teachers are responsible for teaching integrated art education as a part of the program in earlier years. When used in the class, integration supports and enriches the qualities and skills in all program fields. For that reason, art is the complementary components of general educational programs (Cevher Kalburan, 2012; Jackman, 2012). The content of art, the learning and teaching strategies are given in general education programs and besides that children are provided to express themselves personally and socially (Mercin \& Alakuş, 20017; Garvis \& Pendegast, 2011). One of these skills is social skills. Social skills are the ones allowing to start and carry on positive social relations with others like communication, problem solving, decision making, peer relations and managing oneself. Attaining social skills and making it permanent could be realized with the repetition of these skills in the family, school and other living areas (Kapıkıran, İvrendi \& Adak, 2006).

Teachers could use different strategies to make the children attain the skills of making connection with peers and carrying it on, controlling himself, adapting to the environment, carrying out a task in the group, coping with aggressive behaviours, making plans and solving problems. Teachers support children to make them experience speaking skills, respecting others' rights, waiting in the line, solution of a conflict, solving social problems and feeling empathy (Özyürek, Begde \& Ferah Yavuz, 2014). For that reason, the teacher must include aesthetic interaction and artistic works in artistic teaching. Aesthetic interactions inform us about complex thinking, observing, choosing, differentiation, visualizing, hypothesizing, verification, adaptation, perception, and revising, criticizing, reflection, comparing, analysing, synthesizing and evaluating the artistic experiences. These interactions enrich and enlarge intercultural sense. The fact that the artistic works of children become valuable is a result of expressing their thoughts of the views of their friends and teachers over art. Ideas over artistic works make children equipped with necessary sources and skills in order to enrich and express artistic experiences. These studies enlarge the language and communication skills of children, deepen their world views and improve their social skills (Wong, 2007; Bell, 2012).

For that reason, teachers could make the artistic activities more meaningful by talking to children over what they do in activities, how they feel while doing them etc. In addition, children's self-esteem improves when teachers talk about the features and qualities of their works and they learn how to look at an artistic work of others, see the aesthetic features and discuss about them. The art works produced in groups provide children with making plans and realizing them together in cooperation. While working in cooperation, they should learn such skills as how to share objects, listen to others, how and when to work. With the art education given in this way, multi way development and particularly the development of social skills are supported (Ulutaş \& Ersoy, 2004; Toy, 2006). In order to support the social skills of children, it is of great importance that teachers should provide qualitative artistic experiences in their classes and use art both as a purpose and a tool by learning artistic education through integrated artistic education and teaching it and deepening other academic learning (Terraccino, 2011; Yazıcı, Yaman Baydar \& Pınarcık, 2016). Within this perspective, it is of vital importance that these kinds of artistic activities developed in children from early ages onwards make children attain awareness towards social skills in the future. In this sense, the research was carried out to determine the effect of "Art Education Program" on the social skills of the children at the age of 61-72 months attending to a kindergarten.

\section{Method}

This research has been carried out in order to investigate the effect of "Art Education Program" on social skills of 61-72 months old children. In this part of the study which has been conducted in accordance to with this purpose, research model, working group, data collection tools and analysis of data are presented.

\subsection{Research Model}

In this study, pre-test/post-test control group research design has been applied in order to analyze the effect of "Art Education Program" on 61-72 months old children who attend to a preschool education institution. Experimental researches are aimed to examine the differences which were created by researcher on dependent variable. In experimental research designs, the main aim is to examine the cause and effect relationship which is created between variables. In this research, without an unbiased assignment, two groups were matched in terms of literacy skills (Büyüköztürk, Kılıç-Çakmak, Akgün, Karadeniz \& Demirel, 2012). The study was carried out without equal numbers of children in 
accordance with control-group pre-test/post-test; as attempting to equalize the number of subjects in the experimental and control groups might lead to data loss and other problems in the event of the exclusion of some children from the class design (Büyüköztürk, 2014).

\subsection{Study Group}

Study group of is consisted of the 61-72 months old children, with normal development, who attend to the independent preschools affiliated to the Ministry of Education in the district of Kecioren, Ankara in 2015-2016 academic year. Study group included a total of 51 children (experiment $n=26$; control $n=25$ ) who were selected by random sampling method, and not previously received any special education program. Demographic features of the study groups were;

Sex: in the experimental group, $49.0 \%$ of children were girls, $51.0 \%$ of children in experimental group were boys and $36.8 \%$ of children in control group were girls, $63.2 \%$ of children in control group were boys;

Birth order: in experimental group, $49.4 \%$ of children was firstborn, $37.6 \%$ of children in experimental group were last child in their family and $13.0 \%$ of children are middle child, $54.3 \%$ of children in control group were firstborn, $30.7 \%$ of children in control group were middle child and $15.0 \%$ of children in control group were last child;

Pre-school experience: in experimental group, $42.4 \%$ of children attended to preschool for $13-24$ months, $34.0 \%$ of children in experimental group attended to preschool for 7-12 months $23.6 \%$ of children in experimental group attended to preschool for more than 24 months; in control group, $54.2 \%$ of children attended to preschool for $13-24$ months, $43.0 \%$ of children attended to preschool for 7-12 months, $22.8 \%$ of children attended to preschool for more than 24 months.

\subsection{Data Collection Tools}

In this study, as data collection tools, "General Information Form" was used in order to collect general information about children and "SSES" which was developed by Avc1oğlu (2007) and the validity and reliability study of which was accomplished, was used.

\section{Social Skills Evaluation Scale/SSES}

"SSES" was developed by Avcioğlu (2007) for the preschool children at the age of 4-6 and a scale containing the social skills. The dimensions of the social skills measured by the sub-scales in "SSES" were defined below.

- Interpersonal Skills (IS): Interpersonal skill dimension which is of importance in maintaining mutual interaction among individuals is made of 15 items.

- The Skills of Controlling the Anger Behaviours and Adapting to Changes (SCABC): This dimension made up of skills allowing them to control both their own and others' anger behaviours in the social interaction of individuals and adapting to changes easily comprises 11 items.

- The Skills to Cope with Peer Pressure (SCPP): This dimension which is made up of the skills allowing the individuals to cope with various pressures likely to be encountered by their peers within social interaction comprises 10 items.

- The Skills to Control Oneself (SCO): This dimension which is made up of the skills allowing the individuals to control themselves on their social behaviours comprises 4 items.

- The Skills of Verbal Expression (SVE): This dimension which is made up of the skills forming an onset in the start and maintenance of interaction among individuals comprises 7 items.

- The Skills to Accept the Outcomes (SAO): This dimension which is made up of the skills allowing the individuals to accept various outcomes they could encounter comprises 4 items.

- The Skills to Listen (SL): This dimension which is made up of the listening skills forming an onset in the start and maintenance of interaction among individuals comprises 5 items.

- Skills to Form Objectives (SFO): This dimension which is made up of the skills allowing individuals form an objective free from others and develop these objectives comprises 3 items.

- Skills to Complete Tasks (SCT): This dimension which is made up of the skills helping individuals to fulfil the tasks for which they are responsible comprises 3 items.

The scale with 62 items that was filled out by teacher was expressed as Likert Type gradation scale of with five points (Never, Rarely, Sometimes, Frequently, Always).

Validity and Reliability Study: The reliability study of the scale was determined through the methods of Cronbach Alpha Coefficient, split half reliability coefficient and test and re-test. The alpha internal consistency coefficient for factor and whole scale was found $.95, .94, .92, .91, .85, .95, .87, .78, .88$ and .98 respectively. The test, re-test reliability coefficients of the scale were found $.91, .89, .85, .87, .84, .85, .85, .62, .82$ and .89 respectively. The test, re-test 
reliability coefficients of the scale for sub-factors and the whole scale were $.98, .73, .82, .78, .83, .73, .90, .79, .60$ and .83 respectively (Avcığlu, 2007). In the current, reliability total SSES Cronbach Internal Consistency Coefficient was .87 in this study.

\section{Art Education Program}

"Art Education Program" bases upon supporting the social skills of the children at the age of 61-72 months in the preschool period. Considering the items of "Art Education Program"; the "Pre-school Education Program (2013)" which is implemented by the Ministry of Education for 36-72 months old children, have been examined and associated acquisition and development indicators have been selected. While determining the indicators of acquisition and development, a single area of growth hasn't been kept in the forefront; all areas of development have been supported in accordance with the children's educational needs. "Art Education Program" prepared and implemented for the study has the following features:

- It is suitable developmentally and child centred.

- Activities are planned to be implemented in a time period varying between about 40 minutes to an hour, in three week days for eight weeks in total.

- Art works associated with various activities including drama, play, literacy, science, creativity, math, music and movement activities,

- Different methods and techniques (Drama, play, music, question and answer, problem solving etc. ) are employed for a given activity,

- Activities are presented in three phases from basic to complicated level,

- Play-based learning is central to all activities.

- "Art Education Program" consists of 24 unique activities of musical art, visual art, kinesthetic art and dramatic art.

Following of the preparation process of "Art Education Program", program has been introduced to 5 experts. Experts assessed the comprehensibility and relevance of the activities with the aim of program by using the triple rating scale such as "Never", "Average", "Full". After obtaining expert opinions, they were combined in a form and assessed by considering opinions of experts and analyzes were performed for each question. The percentages of compromise which are known as the reliability of raters were calculated to determine level of the harmony between experts. To determine the consensus of researchers and experts on the assessment, the formula which was indicated by Miles and Haberman (1994) was used. According to this formula was calculated as Percentage of Compromise $=[$ Consensus $/$ (Consensus + Dissidence)] x100] (Baştürk 2009). As a result of this calculation, it was indicated that there was a harmony above $90 \%$ among experts, suggested changes for "Art Education Program" was done and shaped in final version and got ready for the main implementation.

\subsection{Data Collection}

In order to assess the effects of "Art Education Program" on social skills, "SSES" for 61-72 months Old Children pretest was implemented in experimental and control group on $10^{\text {th }}-14^{\text {th }}$ October, 2016. After pretests, on $17^{\text {th }}$ October- $9^{\text {th }}$ December, 2016 "Art Education Program" was implemented in experimental group. MEB Preschool Education Program was implemented by their teacher in control group. "Research Test of "SSES" was implemented as test in experiment and control group on $12^{\text {th }}-16^{\text {th }}$ December, 2016.

\subsection{Data Analysis}

The data of research was resolved using SPSS statistical program. In the study, descriptive statistics such as frequency and percentage assessment of the demographic characteristics of the children were used. Scores of "SSES" were examined in order to see there was either normal distribution or not by the Kolmogorov-Smirnov Test (Özdamar, 2004). As a result of Kolmogorov-Smirnov normality test, it was seen that data was normally distributed ( $>0.05)$.

As a result of the normality test in the analysis of data; as the "SSES" pre-test/post-test scores of the children in the experiment and control groups had normal distribution, inter-group comparisons were analysed through Independent Sampling T-Test and in-group comparisons were analysed with Paired Sampling T-Test. While from Independent Sampling T-Test tests examines showing differences in a meaningful way from each of the scores obtained from unrelated samples, Paired Sampling T-Test assess the scores of related two measurement set whether it differ or not (Büyüköztürk, 2009). While investigating the differences between categorical variables, significance level was set to be 0.05 and when it is $p<0.05$, it means that there is a significant difference between the groups and when it is $p>.05$, it means there is no significant difference between the groups (Büyüköztürk, et al. 2012). 
Additionally, in the study the covariance analysis (ANCOVA) was also used to determine whether the differences in the posttest scores of experimental and control groups after the experimental procedure depend on pretest scores. In a research, the covariance analysis, is a technique, which provides statistical control of another variable or variables called covariate that have correlation with the dependent variable, other than the independent variable of which the effect is tested (Lord, 1960). The aim of implementation of this test is pulling out the changes caused by the covariate from the posttest scores that are considered as the dependent variables, and afterwards determining whether the change in the dependent variable is due to the change in the independent variable, or not (Punch, 2005). In the analysis, the posttest scores are considered as the dependent variable, the group variable as fixed variable, and the pretest scores as covariate.

- In order to test whether the experimental and control groups were received from the same universe, the comparisons of the average scores of the "SSES" pre-test were analyzed using the Independent Samples T-Test.

- In order to determine whether there is a significant difference between the pre-test and post-test score averages of "SSES" in each group, the Paired Sample T-Test was applied.

- In order to determine whether the "Art Education Program", affected the social skills in children, Independent Samples T-Test was applied to compare post-test score averages of the experiment and control groups.

- The posttest scores of experiment and control groups were also compared by covariance analysis in order to determine any significant effect occurred when the effect of the pretest scores are eliminated.

\section{Results}

The results of the research, which was carried out to examine the effects of the "Art Education Program" on the social skills of 61-72 months old children, who attend preschool, are presented below.

Table 1. T-Test Scores in the Independent Groups in term of "SSES" Sub-Dimension of the Children in Experiment and Control Groups and Total Pre-Test Scores

\begin{tabular}{|c|c|c|c|c|c|c|c|}
\hline SSES & Group & $\mathbf{N}$ & $\mathbf{X}$ & $\mathbf{S}$ & df & $\mathbf{t}$ & p \\
\hline \multirow{2}{*}{ IS } & Experiment & 26 & 45.76 & 8.71 & 49 & \multirow{2}{*}{39} & \multirow{2}{*}{26} \\
\hline & Control & 25 & 47.20 & 7.17 & 49 & & \\
\hline \multirow{2}{*}{ SCABC } & Experiment & 26 & 30.38 & 6.41 & 49 & \multirow{2}{*}{409} & \multirow{2}{*}{65} \\
\hline & Control & 25 & 32.76 & 5.56 & 49 & & \\
\hline \multirow{2}{*}{ SCPP } & Experiment & 26 & 26.42 & 6.61 & 49 & \multirow{2}{*}{29} & \multirow{2}{*}{99} \\
\hline & Control & 25 & 27.40 & 6.57 & 49 & & \\
\hline \multirow{2}{*}{ SCO } & Experiment & 26 & 11.11 & 2.86 & 49 & \multirow{2}{*}{013} & \multirow{2}{*}{16} \\
\hline & Control & 25 & 11.80 & 2.14 & 49 & & \\
\hline \multirow{2}{*}{ SVE } & Experiment & 26 & 21.19 & 4.51 & 49 & \multirow{2}{*}{64} & \multirow{2}{*}{40} \\
\hline & Control & 25 & 22.32 & 3.31 & 49 & & \\
\hline \multirow{2}{*}{ SAO } & Experiment & 26 & 10.34 & 2.85 & 49 & \multirow{2}{*}{279} & \multirow{2}{*}{.07} \\
\hline & Control & 25 & 11.12 & 2.36 & 49 & & \\
\hline \multirow[b]{2}{*}{ SL } & Experiment & 26 & 14,80 & 3.56 & 49 & \multirow[b]{2}{*}{42} & \multirow{2}{*}{61} \\
\hline & Control & 25 & 15.24 & 3.41 & 49 & & \\
\hline \multirow{2}{*}{ SFO } & Experiment & 26 & 8.65 & 2.48 & 49 & \multirow{2}{*}{65} & \multirow{2}{*}{39} \\
\hline & Control & 25 & 9.44 & 1.85 & 49 & & \\
\hline \multirow{2}{*}{ SCT } & Experiment & 26 & 9.46 & 2.00 & 49 & \multirow{2}{*}{051} & \multirow{2}{*}{.98} \\
\hline & Control & 25 & 10.00 & 1.97 & 49 & & \\
\hline \multirow{2}{*}{ Total SSES } & Experiment & 26 & 178.15 & 31.85 & 49 & \multirow{2}{*}{39} & \multirow{2}{*}{26} \\
\hline & Control & 25 & 187.80 & 26.99 & 49 & & \\
\hline
\end{tabular}

As given in Table 1, depending on t-test scores in the independent groups in term of "SSES" sub-dimension of the children in experiment and control groups and total pre-test scores, no statistically significant difference was found between the IS ( $\mathrm{t}(49)=-.639, \mathrm{p}>0.05), \operatorname{SCABC}(\mathrm{t}(49)=-1.409, \mathrm{p}>0.05)$, SCPP $(\mathrm{t}(49)=-.529, \mathrm{p}>0.05), \operatorname{SCO}(\mathrm{t}(49)=$ $-1.013, \mathrm{p}>0.05)$, SVE ( $(49)=-.964, \mathrm{p}>0.05)$, SAO ( $\mathrm{t}(49)=-1.279, \mathrm{p}>0.05)$, SL $(\mathrm{t}(49)=-.442, \mathrm{p}>0.05)$, SFO ( $\mathrm{t}(49)=$ $-.965, \mathrm{p}>0.05)$, SCT $(\mathrm{t}(49)=-1.051, \mathrm{p}>0.05)$ sub-dimensions of the children in the experiment and control groups and total pre-test mean scores $(\mathrm{t}(49=-.639, \mathrm{p}>0.05)$.

As given in Table 2, depending on t-test scores in term of "SSES" sub-dimension of the children in experiment group and total pre-test/post test scores, a statistically significant difference was found between IS (t $(25)=-8.868, \mathrm{p}<0.05)$, $\operatorname{SCABC}(\mathrm{t}(25)=-11.776, \mathrm{p}<0.05), \operatorname{SCPP}(\mathrm{t}(25)=-10.081, \mathrm{p}<0.05), \operatorname{SCO}(\mathrm{t}(25)=-6.974, \mathrm{p}<0.05), \operatorname{SVE}(\mathrm{t}(25)=-7.637$, $\mathrm{p}<0.05), \mathrm{SAO}(\mathrm{t}(25)=-8.289, \mathrm{p}<0.05)$, SL $(\mathrm{t}(25)=-5.084, \mathrm{p}<0.05)$, SFO ( $(25)=-4.521, \mathrm{p}<0.05), \operatorname{SCT}(\mathrm{t}(25)=-5.984$, $\mathrm{p}<0.05)$ sub-dimensions of the children in the experiment group and total pre-test/post-test mean scores $(\mathrm{t}(25)=-10.734$, $\mathrm{p}<0.05)$. 
Table 2. T-Test Scores in Term of "SSES" Sub-Dimension of the Children in Experiment Group and Total Pre-Test/Post-Test Scores

\begin{tabular}{|c|c|c|c|c|c|c|c|}
\hline SSES & Group & $\mathbf{N}$ & $\mathbf{X}$ & $\mathbf{S}$ & df & $\mathbf{t}$ & p \\
\hline \multirow{2}{*}{ IS } & Experiment Pre & 26 & 45.76 & 8.71 & 25 & \multirow[t]{2}{*}{-8.868} & \multirow{2}{*}{.000} \\
\hline & Experiment Post & 26 & 63.88 & 6.73 & 25 & & \\
\hline \multirow{2}{*}{ SCABC } & Experiment Pre & 26 & 30.38 & 6.41 & 25 & \multirow{2}{*}{-11.776} & \multirow{2}{*}{.000} \\
\hline & Experiment Post & 26 & 46.26 & 6.13 & 25 & & \\
\hline \multirow{2}{*}{ SCPP } & Experiment Pre & 26 & 26.42 & 6.61 & 25 & \multirow{2}{*}{-10.081} & \multirow{2}{*}{.000} \\
\hline & Experiment Post & 26 & 41.03 & 4.34 & 25 & & \\
\hline \multirow{2}{*}{ SCO } & Experiment Pre & 26 & 11.11 & 2.86 & 25 & \multirow{2}{*}{-6.974} & \multirow{2}{*}{.000} \\
\hline & Experiment Post & 26 & 16.07 & 2.57 & 25 & & \\
\hline \multirow{2}{*}{ SVE } & Experiment Pre & 26 & 21.19 & 4.51 & 25 & \multirow{2}{*}{-7.637} & \multirow{2}{*}{.000} \\
\hline & Experiment Post & 26 & 29.38 & 3.06 & 25 & & \\
\hline \multirow{2}{*}{ SAO } & Experiment Pre & 26 & 10.34 & 2.85 & 25 & \multirow{2}{*}{-8.289} & \multirow[b]{2}{*}{.000} \\
\hline & Experiment Post & 26 & 15.42 & 2.43 & 25 & & \\
\hline \multirow{2}{*}{ SL } & Experiment Pre & 26 & 14.80 & 3.56 & 25 & \multirow{2}{*}{-5.084} & \multirow{2}{*}{.000} \\
\hline & Experiment Post & 26 & 19.76 & 2.76 & 25 & & \\
\hline \multirow{2}{*}{ SFO } & Experiment Pre & 26 & 8.65 & 2.48 & 25 & \multirow{2}{*}{-4.521} & \multirow{2}{*}{.000} \\
\hline & Experiment Post & 26 & 11.38 & 1.67 & 25 & & \\
\hline \multirow{2}{*}{ SCT } & Experiment Pre & 26 & 9.46 & 2.00 & 25 & \multirow{2}{*}{-5.984} & \multirow{2}{*}{.000} \\
\hline & Experiment Post & 26 & 12.53 & 1.67 & 25 & & \\
\hline \multirow{2}{*}{ Total SSES } & Experiment Pre & 26 & 178.15 & 31.85 & 25 & \multirow{2}{*}{-10.734} & \multirow{2}{*}{.000} \\
\hline & Experiment Post & 26 & 255.76 & 18.55 & 25 & & \\
\hline
\end{tabular}

Table 3. T-Test Scores in term of "SSES" Sub-Dimension of the Children in Control Group and Total Pre-Test/Post-Test Scores

\begin{tabular}{|c|c|c|c|c|c|c|c|}
\hline SSES & Group & $\mathbf{N}$ & $\mathbf{X}$ & $\mathbf{S}$ & df & $\mathbf{t}$ & p \\
\hline & Control Pre & 25 & 47.20 & 7.17 & 24 & \multirow{2}{*}{-6.952} & \\
\hline IS & Control Post & 25 & 51.76 & 6.37 & 24 & & .000 \\
\hline SCABC & Control Pre & 25 & 32.76 & 5.56 & 24 & \multirow{2}{*}{-5.626} & \multirow{2}{*}{.000} \\
\hline SCABC & Control Post & 25 & 35.84 & 6.01 & 24 & & \\
\hline \multirow{2}{*}{ SCPP } & Control Pre & 25 & 27.40 & 6.57 & 24 & \multirow{2}{*}{-6.936} & \multirow{2}{*}{.000} \\
\hline & Control Post & 25 & 32.16 & 6.49 & 24 & & \\
\hline \multirow{2}{*}{ SCO } & Control Pre & 25 & 11.80 & 2.14 & 24 & \multirow{2}{*}{-3.375} & \multirow{2}{*}{.003} \\
\hline & Control Post & 25 & 12.84 & 2.77 & 24 & & \\
\hline \multirow{2}{*}{ SVE } & Control Pre & 25 & 22.32 & 3.31 & 24 & \multirow{2}{*}{-3.063} & \multirow{2}{*}{.000} \\
\hline & Control Post & 25 & 23.64 & 4.01 & 24 & & \\
\hline \multirow{2}{*}{ SAO } & Control Pre & 25 & 11.12 & 2.36 & 24 & \multirow{2}{*}{-4.625} & \multirow{2}{*}{.000} \\
\hline & Control Post & 25 & 12.56 & 2.14 & 24 & & \\
\hline \multirow{2}{*}{ SL } & Control Pre & 25 & 15.24 & 3.41 & 24 & \multirow[b]{2}{*}{-5.331} & \multirow[b]{2}{*}{.000} \\
\hline & Control Post & 25 & 16.72 & 3.25 & 24 & & \\
\hline \multirow{2}{*}{ SFO } & Control Pre & 25 & 9.44 & 1.85 & 24 & \multirow[b]{2}{*}{-1.984} & \multirow[b]{2}{*}{.049} \\
\hline & Control Post & 25 & 10.16 & 1.92 & 24 & & \\
\hline \multirow{2}{*}{ SCT } & Control Pre & 25 & 10.00 & 1.97 & 24 & \multirow{2}{*}{-2.400} & \multirow{2}{*}{.024} \\
\hline & Control Post & 25 & 10.44 & 2.14 & 24 & & \\
\hline \multirow{2}{*}{ Total SSES } & Control Pre & 25 & 187.80 & 26.99 & 24 & \multirow{2}{*}{-8.050} & \multirow{2}{*}{.000} \\
\hline & Control Post & 25 & 206.12 & 29.95 & 24 & & \\
\hline
\end{tabular}

As given in Table 3, depending on t-test scores in term of "SSES" sub-dimension of the children in control group and total pre-test/post-test scores, a statistically significant difference was found between IS $(\mathrm{t}(24)=-6.952, \mathrm{p}<0.05)$, $\operatorname{SCABC}(\mathrm{t}(24)=-5.626, \mathrm{p}<0.05), \operatorname{SCPP}(\mathrm{t}(24)=-6.936, \mathrm{p}<0.05), \mathrm{SCO}(\mathrm{t}(24)=-3.375, \mathrm{p}<0.05), \operatorname{SVE}(\mathrm{t}(24)=-3.063$, $\mathrm{p}<0.05)$, SAO ( $\mathrm{t}(24)=-4.625, \mathrm{p}<0.05)$, SL ( $\mathrm{t}(24)=-5.331, \mathrm{p}<0.05)$, SFO ( $\mathrm{t}(24)=-1.984, \mathrm{p}<0.05), \mathrm{SCT}(\mathrm{t}(24)=-2.400$, $\mathrm{p}<0.05)$ sub-dimensions of the children in the control group and total pre-test/post-test mean $\operatorname{scores}(\mathrm{t}(24)=-8.050$, $\mathrm{p}<0.05)$.

As shown in Table 4, depending on t-test scores in the independent groups in term of "SSES" sub-dimension of the children in experiment and control groups and total post-test scores, a statistically significant difference was found between the IS $(\mathrm{t}(49)=6.601, \mathrm{p}<0.05), \operatorname{SCABC}(\mathrm{t}(49)=6.129, \mathrm{p}<0.05), \operatorname{SCPP}(\mathrm{t}(49)=5.755, \mathrm{p}<0.05), \operatorname{SCO}(\mathrm{t}(49)=$ 5.757, $\mathrm{p}<0.05)$, SVE ( $(49)=5.757, \mathrm{p}<0.05), \operatorname{SAO}(\mathrm{t}(49)=4.316, \mathrm{p}<0.05), \operatorname{SL}(\mathrm{t}(49)=2.423, \mathrm{p}<0.05), \operatorname{SFO}(\mathrm{t}(49)=$ $3.610, \mathrm{p}<0.05)$, SCT $(\mathrm{t}(49)=3.902, \mathrm{p}<0.05)$ sub-dimensions of the children in the experiment and control groups and total post-test mean scores $(\mathrm{t}(49)=4.450, \mathrm{p}<0.05)$. 
Table 4. T-Test Scores in the Independent Groups in term of "SSES" Sub-Dimension of the Children in Experiment and Control Groups and Total Post-Test Scores

\begin{tabular}{lllccccc}
\hline SSES & Group & $\mathbf{N}$ & $\mathbf{X}$ & $\mathbf{S}$ & $\mathbf{d f}$ & $\mathbf{t}$ & $\mathbf{p}$ \\
\hline \multirow{2}{*}{ IS } & Experiment & 26 & 63.88 & 6.73 & 49 & & \\
& Control & 25 & 51.76 & 6.37 & 49 & 6.601 & .000 \\
SCABC & Experiment & 26 & 46.26 & 6.13 & 49 & 6.129 & .000 \\
& Control & 25 & 35.84 & 6.01 & 49 & & \\
SCPP & Experiment & 26 & 41.03 & 4.34 & 49 & 5.755 & .000 \\
& Control & 25 & 32.16 & 6.49 & 49 & & \\
SCO & Experiment & 26 & 16.07 & 2.57 & 49 & 5.757 & .000 \\
& Control & 25 & 12.84 & 2.77 & 49 & & \\
SVE & Experiment & 26 & 29.38 & 3.06 & 49 & 5.757 & .000 \\
& Control & 25 & 23.64 & 4.01 & 49 & & \\
SAO & Experiment & 26 & 15.42 & 2.43 & 49 & 4.316 & .000 \\
& Control & 25 & 12.56 & 2.14 & 49 & & \\
SL & Experiment & 26 & 19.76 & 2.76 & 49 & 2.423 & .019 \\
& Control & 25 & 16.72 & 3.25 & 49 & & \\
SFO & Experiment & 26 & 11.38 & 1.67 & 49 & 3.610 & .001 \\
& Control & 25 & 10.16 & 1.92 & 49 & 3.60 & \\
SCT & Experiment & 26 & 12.53 & 1.67 & 49 & 3.902 & .000 \\
Total & Control & 25 & 10.44 & 2.14 & 49 & & \\
SSES & Experiment & 26 & 255.76 & 18.55 & 49 & 4.450 & .000 \\
\hline
\end{tabular}

In order to have a better visual understanding of the difference regarding the pre-test/posttest results between the experiment group upon which the "Art Education Program" was implemented and control group on which no action was taken, a line chart was utilized. Differences between the scores obtained from both experimental and control groups before and after the experimental process, were shown in Figure 1.

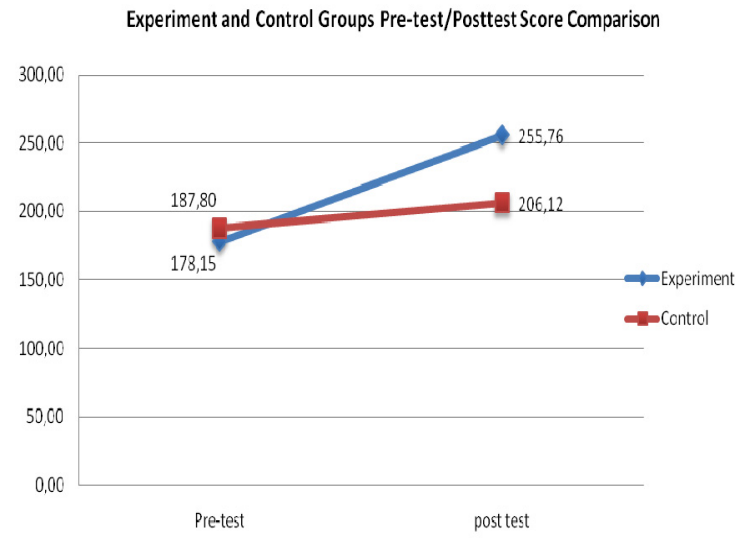

Figure 1. Experiment and Control Groups Pre-test/Posttest Score Comparison

In the comparison of the difference between the scores, the experiment and control groups obtained in "SSES", it was found that despite an increase of 77.61 points in the experiment group, the increase in the control group was 18.32. As a result, the experiment group's scores were higher than the control group, and the difference was statistically significant with $\mathrm{t}$ test $(\mathrm{p}<.05)$. According to these results obtained, it can be said that "Art Education Program" improves children's social skills significantly. After the difference between the average scores, the covariance analysis was used in order to determine whether there was still a significant difference between the posttest scores of the experiment and control groups when the effect of the pre-test was removed (Büyüköztürk, 1998). In the analysis, posttest scores are considered as dependent variables, group variables as fixed variables and the pre-test scores as covariates, and analytical results were shown in Table 5.

When the Table 5 was analyzed, it was determined that there was a significant difference between the posttest scores of the children $\left(\mathrm{F}_{1-47}=37.243 ; \mathrm{p}=0.000\right)$. According to these results obtained, it was found that the children's "SSES" post-test results had a significant difference regarding their position of being in experiment and control group. 
Table 5. The Covariance Analysis Results That the Posttest Scores Are Considered As Dependent Variables

\begin{tabular}{|c|c|c|c|c|c|c|}
\hline Source & Sum of Squares & df & Mean Square & $\mathbf{F}$ & Sig. & $\eta 2$ \\
\hline Corrected Model & $50062.965^{\mathrm{a}}$ & 3 & 16687.655 & 68.181 & & .813 \\
\hline Intercept & 19158.260 & 1 & 19158.260 & 78.275 & & .625 \\
\hline Group & 15362.337 & 1 & 15362.337 & 62.766 & & .572 \\
\hline Pretest & 12888.220 & 1 & 12888.220 & 52.657 & & .528 \\
\hline Group * Pre-test & 9115.354 & 1 & 9115.354 & 37.243 & & .442 \\
\hline Error & 11503.544 & 47 & 244.756 & & & \\
\hline Total & 2793151.000 & 51 & & & & \\
\hline Corrected Total & 61566.510 & 50 & & & & \\
\hline
\end{tabular}

$\mathrm{R}^{2}=0.813$ (Adjusted $\mathrm{R}^{2}=0.801$ )

\section{Discussion}

We investigated the impact of "Art Education Program" on the social skills of preschool children. "Art Education Program was integrated with a standard educational program and its effect was tested by "SSES". Study results showed that "Art Education Program" significantly improved the social skills in all domains as well as overall scores.

The children from the experiment and control groups were from the same universe before the "Art Education Program" was implemented since pretest scores from the "SSES" of experiment and control group were comparable. In other words, children in the control group and in the experiment group are considered to be similar in terms of the measured characteristic.

It is likely to say that the Ministry of Education program supporting the artistic activities implemented by the classroom teachers to the children in the control group had a positive effect on the social skills of children. This result could be regarded as an expected case. The difference in the pre-test/post-test scores evaluating the social skills of the children in the control group could be related to the application of the artistic activities in a way that classroom teachers could support the social skills and their active involvement in the learning process of the children

It was found that there was a significant difference between the "SSES" post-test scores the children in the experiment and control groups. Depending on this result, it is likely to think that "Art Education Program had a significant difference compared to the control group on which no process was applied in terms of the social skills of the children.

Upon the revising of the researches carried out, it was found that Erbay \& Doğru (2010) investigated the effect of drama education, one of the sub-branches of art, on the social communication skills of children under six years of age attending to a kindergarten. At the end of the research, they found that drama education had a positive effect upon the social communication of children.

Duffy \& Fuller (2000) investigated the program of music therapy program which is a sub-branch of art on the social skills of children in their studies. They found that the eight-week education had an effect on the social skills of children.

Atasavun Uysal \& Düger (2012) examined the effect of visual perception education, a sub-branch of art, on the social skills of children in their study and found that it had an effect on the social skills of children.

Upon revising the related literature, it was found that musical art helps improve the linguistic and spatial reasoning skills as well as making children attain such habits that are essential for life as sharing a contented surrounding with other children, being a part of a group, doing something with friends, being tidy and disciplined, waiting for his turn and being patient (Başer, 2004; Lucas, 2014). Visual Arts is a social activity as well as improving linguistic and intellectual skills. In addition, it makes people attain a great many values such as learning visual language, formation of art taste, the skill to think originally as a different way of communication, improving physical development, accelerating mental development, improving imagination, starting to build up culture and forming self-confidence (Ayaydın, 2010; Hardy, 2011). Kinesthetic art supports and improves the physical development of children, their social and emotional development and cognitive developments. Children discuss and listen to the views of their own and others' dances. (Garvis, 2012). Dramatic art makes children attain some qualities such as self-confidence, knowing oneself, creativity, critical view, going beyond oneself, producing practical and new skills for the real life problems (Kara \& Çam, 2007). In addition, it also plays a significant role in their mental circles and in their personality developments in terms of expressing their opinion and feeling comfortable (Garvis, 2012: 88; Lucas, 2014: 26). In this sense, art education is of importance as it supports the social skills of children.

The results of the research and what was obtained in the literature given above correspond that they are effective in increasing the social skills of children. The fact that the "Art Education Program" is made up of activities comprising the whole branches of art (musical, visual, kinesthetic and dramatic) is integrated with different types of activities (art, drama, mathematics, science etc.), that an education environment is prepared with an adequate equipment to increase the perception of children, active involvement of children in the learning life through different methods and techniques, 
the activities are play based and learning centered and that the activities are applied systematically might be reason that "SSES" scores are statistically significant in favor of posttest in children in the experiment group. In this sense It is likely to say that the "Art Education Program applied to the children in the experiment group had a positive effect on the social skills of children.

Under the light of the data obtained from the study, following suggestions have been made;

- As the "Art Education Program" can be integrated with the other activity areas in pre-school training program, the areas of other disciplines can also be studied.

- In order to the effectiveness of the "Art Education Program", a wider sample group can be provided to benefit from this training by carrying out norm studies.

\section{References}

Atasavun, U. S., \& Düger, T. (2012). Visual perception training on social skills and activity performance in low-vision children. Scandinavian Journal of Occupational Therapy, 19, 33-41. https://doi.org/10.3109/11038128.2011.582512

Avcioğlu, H. (2007). A Study of validity and reliability of the scale for evaluating social skills (4-6 ages). AIBU, Faculty of Education Journal, 7(2), 87-101.

Ayaydın, A. (2010). The values visual arts education gain to individual in preschool period. Erzincan Faculty of Education Journal, 12(1), 187-200.

Başer, F. A. (2004). Contribution of music to child development in preschool period. Sakarya University Education Faculty Journal, 1-10.

Baştürk, S. (2009). Field education in the faculties of science and literature according to secondary education candidate teachers of mathematics, Inönü University Faculty of Education Journal, 10(3), 137-160.

Bell, D. (2012). Talking about art with young people: conversational strategies for aesthetic learning in early childhood setting. University of otago college of education, International Art inn Early Childhood Research Journal, 3(1), $1-17$.

Büyüköztürk, Ş. (1998). Analysis of Covariance (Analysis of Covariance with a Comparative Model). Ankara University. Journal of Faculty of Educational Sciences, 91-105.

Büyüköztürk, Ş. (2009). Guide Book for Analysis of Data for Social Sciences (10 $0^{\text {th }}$ Edition). Ankara: Pegem Academia Publishing.

Büyüköztürk, Ş. (2014). Data Analysis Handbook for Social Sciences (Expanded $19^{\text {th }}$ Edition). Ankara: Pegem Academia Publishing.

Büyüköztürk, Ş., Kılıç Çakmak, E., Akgün, Ö. E., Karadeniz, Ş., \& Demirel, F. (2012). Scientific Research Methods $\left(13^{\text {th }}\right.$ Edition). Ankara: Pegem Academia Publishing.

Cevher Kalburan, N. (2012). Creativity and art in early childhood period. Ankara: Eğiten Books.

Duffy, B., \& Fuller, R. (2000). Role of music therapy in social skills development in children with moderate intellectual disveility. Journal of Applied Research in Intellectual Disveilities, 13, 77-89. https://doi.org/10.1046/j.1468-3148.2000.00011.x

Erbay, F., \& Yildırım, D. S. (2010). The effectiveness of creative drama education on the teaching of social communication skills in mainstreamed students. Procedia Social and Behavioral Sciences, 2, 4475-4479. https://doi.org/10.1016/j.sbspro.2010.03.714

Fox, J. E., \& Schirrmacher, R. (2014). Integrated early childhood art program (Ulutaş, E. Pp. 168-183). Aral, N. ve Duman, G. (Eds.) Art \& creative development for young children (Seventh Edition). U.S.A.: Wadsworth Cengage Learning.

Garvis, S. (2012). Exploring current arts practice in kindergartens \& preparatory classrooms. Australasian Journal of Early Childhood, 37(4), 86-93.

Garvis, S., \& Pendergast, D. (2011). An investigation of early childhood teacher self-efficacy beliefs in the teaching of arts education. International Journal of Education \& The Arts, 12(9), 1-16.

Hardy, W. L. (2011). Arts in early childhood education and the enhancement of learning. Doctoral Thesis (Unpublished), Walden University, Umi Number: 3478542.

Jackman, H. (2012). Early education curriculum: A child's connection to the world (Fifth Edition). U.S.A.: Wadsworth 
Cengage Learning.

Kapıkıran, N., İvrendi, A., \& Adak, A. (2006). Social skill at preschool children: Determining the case: Pamukkale University, Faculty of Education Journal, 19(1), 20-28.

Kara, Y., \& Çam, F. (2007). Effect of creative drama method on the reception of some social skills. Hacettepe University Faculty of Education Journal, 32, 145-155.

Lord, F. M. (1960). Large sample covariance analysis when the control variable is fallible. Journal of the American Statistical Association, 55, 307-321. https://doi.org/10.1080/01621459.1960.10482065

Lucas, C. (2014). An early childhood creative arts program in the state of california: a parallel study using four preschools. Doktoral Thesis (Unpublished), Jones International University, Umi Number: 3632230.

Mercin, L., \& Alakuş, A. O. (2007). Necessity of art education for individual and society. Dicle University Ziya Gökalp Faculty of Education Journal, 9, 14-20.

Özdamar, K. (2004). Package Programs and Analysis of Statistical Data (Vol. 1) $5^{\text {th }}$ Edition. Eskişehir: Kaan Bookstore.

Özsoy, V., \& Şahan M. (2009). The effect of multi field art education method on the student attitude in primary education, 6th grade Painting course Turkish Educational Sciences Journal, 7(1), 205-227.

Özyürek, A., Begde, Z., \& Yavuz, N. F. (2014). The relation between the social skills of preschool education children and the adult interactions around. Social Sciences Journal, 16(2), 115-134.

Punch, K. P. (2005). Introduction to social studies: qualitative and quantitative approaches (Çev: D. Bayrak, H. B. Arslan ve Z. Akyuz), Ankara: Siyasal Kitapevi.

Terracciano, G. (2011). A hands-on music education in-service program for early childhood educators: a quasi-experimental study. Doctoral Thesis (Unpublished), Barry University-Adrian Dominican School of Education.

Toy, B. (2006). A study into the social adaptations and self-respect design levels of the adolescents having and not having art education in the age group of 15-17. Master Thesis (Unpublished) Ankara University, Institute of Applied Sciences, Ankara

Ulutaş, İ., \& Ersoy, Ö. (2004). Art education in preschool period. Gazi University Kastamonu Educational Journal, $12(1), 1-12$.

Wong, B. K. (2007). Conceptions of art in Hong Kong preschool children. Australian Journal of Early Childhood, 32(4), 31-36.

Yazıcı, E., Yaman, B. I., \& Pinarcık. Ö. (2016). A study into the views of preschool teachers over art. E-Journal of International Education Researches, 7(3), 74-88. https://doi.org/10.19160/e-ijer.80596

\section{Copyrights}

Copyright for this article is retained by the author(s), with first publication rights granted to the journal.

This is an open-access article distributed under the terms and conditions of the Creative Commons Attribution license which permits unrestricted use, distribution, and reproduction in any medium, provided the original work is properly cited. 